J. Lake Sci. (湖泊科学) , 2017, 29(1): 160-175

DOI 10. 18307/2017. 0118

(c) 2017 by Journal of Lake Sciences

\title{
鄱阳湖典型洲滩湿地水分补排关系
}

林 欢 $^{1,2}$, 许秀丽 ${ }^{1,2}$, 张 奇 $^{1 * *}$

(1:中国科学院南京地理与湖泊研究所流域地理学重点实验室,南京 210008)

(2: 中国科学院大学,北京 100049)

摘 要: 湿地水分在地下水含水层-土壤一植物一大气界面的运移和转换是维持能量和营养物平衡的重要环节, 水分运移 是湿地生态水文过程研究的关键. 数值模型模拟已成为水分运移研究的重要手段, 然而限于复杂的湿地自然条件及有限 的监测手段, 部分界面水分通量连续动态变化数据的获取及定量化工作较为困难, 目前应用数值模拟法于湿地水分运移 研究的案例仍不多见. 本文以鄱阳湖典型湿地为研究区,构建垂向一维数值模型, 阐释了湖泊水位显著季节性变化条件 下, 湿地水分在不同界面的传输过程, 量化了湿地水分的补排关系. 结果表明: (1) 界面水分通量季节性差异大, 降雨人渗 地面和根系层水分渗漏均对降雨变化响应敏感, 主要集中在 4-6 月, 分别占年总量 $(1450$ 和 $1053 \mathrm{~mm}$ ) 的 $65 \%$ 和 $73 \%$. 土 面蒸发和植物蒸腾年总量为 176 和 $926 \mathrm{~mm}$, 土面蒸发主要受气候条件影响, 植物蒸腾还与植物生长特征有关, 均集中在 $7-$ 8 月,分别占年总量的 $30 \%$ 和 $47 \%$. 深层土壤向浅层根系层的水分补给集中发生在地下水浅埋时段 6-8 月,占年总量 $(609 \mathrm{~mm})$ 的 76\%; (2) 湿地植物根系层水分补排受鄱阳湖水位季节性波动影响显著. 除丰水期 (7-9 月) 主要补给为深 层土壤水外, 退、枯、涨水期的主要补给均为降水人渗. 涨水期 (4-6月) 和枯水期 (12-3 月) 的主要排泄为根系层水分渗 漏, 丰水期以植物蒸腾排泄为主, 退水期 (10-11 月), 土面蒸发与植物蒸腾为主要排泄, 且比重相当. 本文定量了鄱阳湖 典型湿地不同界面水分连续交换关系, 区分了土面蒸发和植物蒸滕, 辨析了各界面水分的主要影响因子, 研究结果有助 于深人理解水分在湿地生态系统地下水含水层-土壤-植物-大气界面的相互作用机制, 认识湖泊洲滩湿地水量平衡, 为 揭示湖泊水情变化对湿地生态的可能影响提供依据,为湿地生态水文过程研究提供重要方法和理论参考.

关键词: 土壤水;根系层;水分补排过程;鄱阳湖湿地;GSPAC 系统;HYDRUS 模型

\section{Relationship of the water supply and drainage in a typical wetland of Lake Poyang}

\author{
LIN Huan ${ }^{1,2}$, XU Xiuli ${ }^{1,2} \&$ ZHANG Qi ${ }^{1 * *}$ \\ (1: Key Laboratory of Watershed Geographic Sciences, Nanjing Institute of Geography and Limnology, Chinese Academy of \\ Sciences, Nanjing 210008, P.R.China) \\ (2: University of Chinese Academy of Sciences, Beijing 100049, P.R.China)
}

\begin{abstract}
Water movement within the groundwater-soil-plant-atmosphere continuum (GSPAC) plays an important role in maintaining energy and nutrient balance in wetland, and water movement is a key to wetland eco-hydrological process. Numerical simulation is an important method for the study of water movement. However there are few examples of numerical simulation on water movement in wetlands, due to the limitation of complicated natural conditions and restricted monitoring methods. In this paper, a typical wetland in Lake Poyang was selected as a study area. One-dimensional vertical numerical model was used to investigate the water movement process through different interfaces and to quantify relationship of the water supply and drainage. The results showed that, (1) the water fluxes through interfaces were in a significant seasonal variation. The rainfall infiltration and the soil water drainage were sensitive to rainfall, which mainly occurred during April and June, taking $65 \%$ and $73 \%$ of the annual amount ( 1450 and $1053 \mathrm{~mm}$ ), respectively. The soil evaporation and vegetation transpiration were related to climatic conditions and the character of plant growth, which were highest in July-August, taking 30\% and 47\% of their annual amount (176 and $926 \mathrm{~mm}$ ), respectively. The upward fluxes from deep soil into root zone mainly occurred in June-August, accounting for $76 \%$ of the annual a-
\end{abstract}

* 国家自然科学基金项目 (41371062) 和国家重点基础研究发展计划项目 (2012CB417003) 联合资助. 2016-01 -29 收稿;2016-04-21 收修改稿. 林欢(1990 ), 女, 硕士研究生;E-mail:15927565451@ 163.com.

** 通信作者;E-mail:qzhang@ niglas.ac.cn. 
mount $(609 \mathrm{~mm})$. (2) The water supply and drainage in plant root zone of the wetland were strongly influenced by the seasonal changes of water level of the Lake Poyang. The main water supply of the root zone is rainfall infiltration except for the high water level period (July-September), in which the upward flow from deep soil is the major water source. In the rising water level (rainy seasons of April-June) and low water level (December-March) periods, the main drainage way is via deep leakage. In the high water level period, the vegetation transpiration is the major water discharge. In lake water level recession period, soil water drainage is mainly via vegetation transpiration and soil evaporation. Our study quantified the water transformation relationship through different interfaces in the typical wetland in Lake Poyang and differentiated the soil evaporation and vegetation transpiration. The results help to better understand the water movement in the GSPAC system and the water balance of lake wetlands, which are essential for lake and wetland managements.

Keywords: Soil water; plant root zone; water supply and drainage process; Lake Poyang wetland; GSPAC system; HYDRUS model

湿地是介于水生和陆生生态系统之间的过渡带, 在时间上呈现周期性干湿交替的动态变化, 在生态上 表现为水陆环境诸因子相互作用、相互影响的生态系统, 水文过程是湿地系统形成和演变的主导环境因 子 $^{[1-2]}$. 湿地地下水含水层-土壤-植物-大气连续体 (Groundwater aquifer-Soil-Plant-Atmosphere Continuum, $\mathrm{GSPAC})^{[3-5]}$ 中各水文要素交替转换频繁, 其中, 土壤水作为物质和能量迁移转换的主要媒介, 是联系大气降 水、地表水、地下水、植物水的重要纽带和中心环节, 其补排过程不仅直接影响着湿地植物的生长与发育, 同 时还通过改变湿地土壤的物理化学地球过程间接影响植物的营养环境和呼吸过程 ${ }^{[6-12]}$. 研究湿地土壤水分 的动态变化及其补排过程对深人认识湿地系统水文与植物相互作用机制有重要意义.

鄱阳湖是我国最大的淡水湖泊,其承纳赣江、抚河、信江、饶河、修水 5 大河流来水, 经调蓄后由湖口注人 长江. 一般而言, 4-6 月 “五河” 来水集中, 鄱阳湖水位抬升, 滩地逐渐淹水; $7-9$ 月鄱阳湖维持高水位, 广大湖 区滩地淹没, 水生植物进人生长旺盛期; 10 月以后, 湖泊水位不断降低, 形成大面积洲滩湿地, 湿生植物相继萌 生 ${ }^{[1]}$. 受鄱阳湖高度动态变化的水文情势的影响, 洲滩湿地“五水” (大气降水、地表水、土壤水、地下水、植物 水) 交替转换频繁, 土壤水的补排过程极其复杂,这直接影响着湿地生物地球化学过程和植物的生长与演替.

目前, 关于鄱阳湖湿地关键水文过程的研究已经开展了很多工作, 众多学者从流域空间尺度出发, 研究 了湖泊水文水动力过程和水循环要素的时空变化及其对气候条件和覆被类型的响应 ${ }^{[13-17]}$, 也有学者通过人 工采样和定位观测探究湿地水文要素的变化及其与生态因子的关系 ${ }^{[18-23]}$. 虽然这些研究能够反映湿地水文 过程的动态变化, 但是对湿地系统内部的界面水分运移规律还没有深刻的认识, 且由于这些水分通量难以 直接观测, 湿地土壤水、植物水 (植物蒸腾) 、大气降水之间界面过程的相关研究尤为缺乏. 大气一土壤界面的 降水人渗是湿地水分补给的重要来源, 大气一植物界面的蒸腾和大气一土壤界面的蒸发则是湿地系统水量平 衡的重要支出项 ${ }^{[3-4]}$, 加之根系层土壤底部界面的水分渗漏和补给, 直接决定了湿地生态系统水分的补排状 况和季节动态. 因此, 量化湿地水分补排关系, 加强对湿地水分的来源构成、排泄去向和界面转化的认识, 对 于深人理解鄱阳湖湿地生态系统的结构和功能有重要意义.

本文选取鄱阳湖吴城自然保护区内的一处典型洲滩湿地作为研究区, 利用 HYDRUS-1D 软件, 构建湿地 GSPAC 系统水分垂向一维运移模型. HYDRUS-1D 是由美国盐土实验室开发的一款用于模拟变饱和介质土 壤水分运移过程的软件 ${ }^{[24]}$, 已经被广泛应用于农田和湿地系统界面水分过程的研究 ${ }^{[25-31]}$. 本文通过数值模 拟法, 定量分析湿地出露条件下单一植被群落覆盖区的水分垂向补排过程, 主要探究大气-植物、大气一土 壤、植物根系层界面水分运移规律和根系层土壤水分均衡情况,揭示鄱阳湖不同水文时段(枯、涨、丰、退水 期) 湿地土壤水分的补给来源及排泄途径, 为全面定量分析鄱阳湖典型湿地水分补排过程和认识 GSPAC 系 统中 “五水” 水分垂向交换过程提供数据支撑, 为未来水文气象情势下湿地水分补排过程动态变化的预测提 供一定的科学依据.

\section{1 试验区及野外数据观测}

\section{1 试验区概况}

试验区 $\left(29^{\circ} 14^{\prime} 34^{\prime \prime} \mathrm{N}, 116^{\circ} 0^{\prime} 11^{\prime \prime} \mathrm{E}\right)$ 位于江西省永修县吴城镇以北的吴城国家自然保护区境内, 地处赣江 
主支与修河交汇后的人湖三角洲, 是鄱阳湖典型的洲滩湿地 (图 1). 试验区土壤主要是粉砂土, 属于亚热带 季风气候,多年平均降水量达到 $1400 \mathrm{~mm}$, 主要集中在 4-6 月,约占全年总雨量的 $47 \%$; 多年平均蒸发量为 $1003 \mathrm{~mm}, 7-10$ 月蒸发最强, 约占全年蒸发量的 50\%. 年内水位季节性波动显著, 地下水位埋深变化范围为 $0 \sim 8 \mathrm{~m}$, 最低水位出现在 1 月, 最高水位出现在 7-8 月, 地下水位可出露地表, 此时地面受湖水上涨而淹没, 9 月之后湖水位消退, 洲滩逐渐出露. 季节性干湿交替形成了发育典型的洲滩植被, 芦苇群落位于中高位滩 地, 长势良好,一般 4 月开始萌发, 7-8 月为生长旺盛期,群落覆盖度在 $90 \%$ 以上.

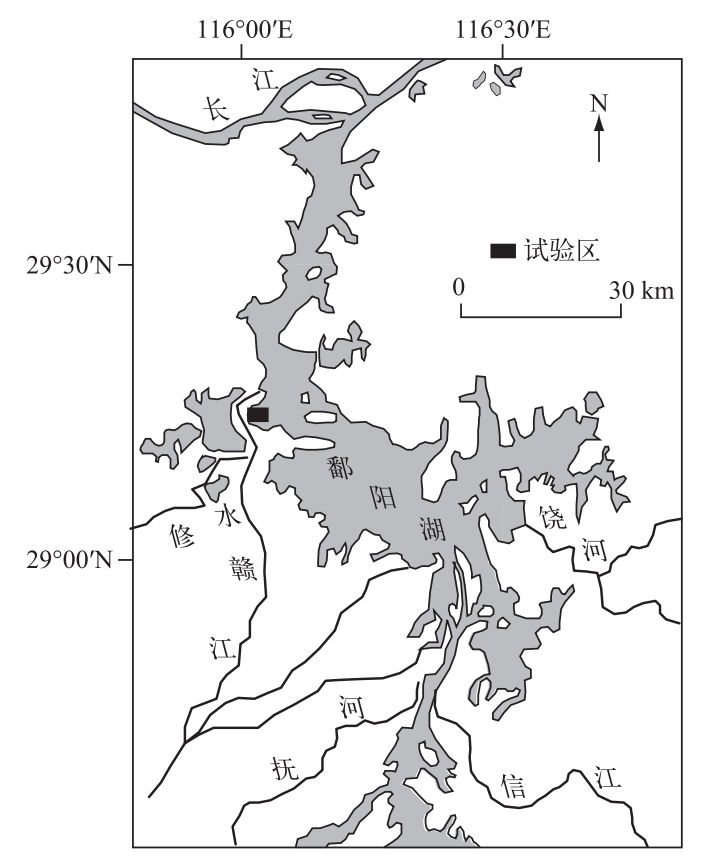

图 1 试验区地理位置

Fig. 1 Location of the study area

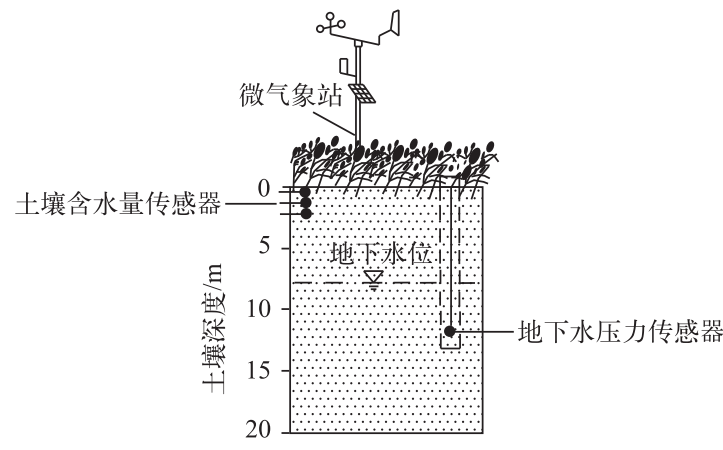

图 2 试验区联合观测系统布设

Fig.2 Joint observation system at the study area

\section{2 观测方法与数据获取}

试验区开展水文-气象要素联合监测 ( 图 2), 布设了地下水位观测井 (井深 $15 \mathrm{~m}$, 地下水压力 传感器 DQC001 距地表 $12.6 \mathrm{~m}$ )、3 组土壤含水量 传感器 MP406 (地面以下 $10 、 50$ 和 $100 \mathrm{~cm}$ ) 和 1 个微气象观测系统 LSI-LASTEM (监测太阳辐射、 气温、湿度、降雨等数据), 数据均自动观测, 记录 频率为 $1 \mathrm{~h}$. 此外, 开展月度的人工植被调查 (植物 均高、根系长度等) 和叶面积指数测量 ( LAI-2200 冠层分析仪测量), 同时采集原状土测定土壤机械 组成及脱湿曲线, 为数值模型的构建提供数据 支撑.

\section{2 典型湿地 GSPAC 系统水分垂向运移模型的构建}

\section{1 模型概化}

试验区土质以粉砂土为主, 渗透性较强, 不易产生壤中流, 加之地面坡降小于 $2 \%$, 在试验区保持出露 时, 非饱和层土壤水分以垂向运动为主, 地下饱和含水层的侧向径流亦微弱, 因此模型主要考虑典型湿地出 
露条件下的 GSPAC 系统垂向一维的水分交换, 概念模型如图 3.

湿地出露条件下根系层土壤水均衡方程为:

$$
R_{\text {in }}+G-D-E_{\mathrm{a}}-T_{\mathrm{a}}=\Delta W
$$

式中, $R_{\mathrm{in}}$ 为降水人渗量 $(\mathrm{mm}) ; G$ 为根系层以下水分的向上补给量 $(\mathrm{mm}) ; D$ 为根系层水分的深层渗漏量 $(\mathrm{mm}) ; E_{\mathrm{a}}$ 为土面蒸发量 $(\mathrm{mm})$; $T_{\mathrm{a}}$ 为植物蒸腾量 $(\mathrm{mm}) ; \Delta W$ 为土壤水储量变化 $(\mathrm{mm})$.

\section{2 数值模型的构建}

本文利用 HYDRUS-1D 软件构建湿地 GSPAC 系统水分垂向运移 数值模型, 主要结构由土壤水运动模块、根系吸水模块和蒸散模块组 成. 边界条件的输人数据包括降雨、太阳辐射、气温、湿度等气象数据 和地下水埋深数据, 初始条件输人数据为初始时刻的土壤含水量, 植 物生长数据包括叶面积指数 $L A I$ 、株高、根系最大深度和根系密度分布 函数. 模型参数主要有土壤水分动力学参数 (残余含水量 $\theta_{\mathrm{r}}$ 、饱和含 水量 $\theta_{\mathrm{s}}$ 、土壤水滞留系数 $\alpha 、 n$ 和饱和渗透系数 $\left.K_{\mathrm{s}}\right)$ 及根系吸水参数 (蒸腾速率减半时土壤负压 $h_{50}$ 和蒸腾速率随负压增加下降坡度 $p$ ).

本文利用 HYDRUS-1D 软件构建模型, 将模拟的土壤含水量与实 测值进行拟合, 从而对模型参数进行率定, 使构建的模型能够还原试 验区真实的水分垂向运移过程,进而利用模型模拟湿地实际降雨人渗 量、土面蒸发和植物蒸腾量、根系层底部水分渗漏和向上补给交换量

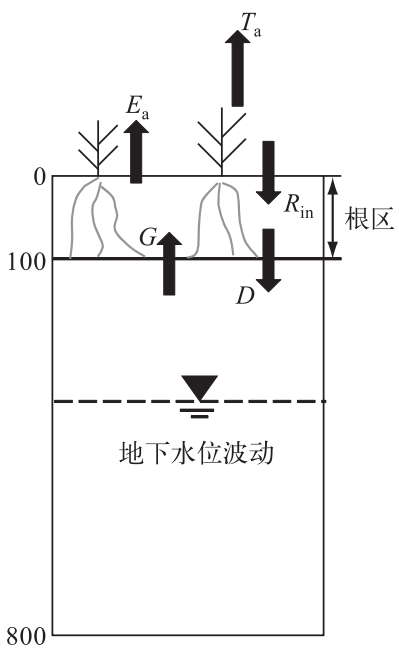

图 3 湿地 GSPAC 系统水分 垂向运移概念模型

Fig. 3 Conceptual model of water vertical movement in wetland GSPAC system 等难以连续观测的界面水分通量.

2.2.1 模型原理与数学描述 土壤水运动模块可数值解析变饱和介质中垂向一维水流运动, 使用一维 Richards 方程描述 ${ }^{[32]}$ :

$$
\frac{\partial \theta}{\partial t}=\frac{\partial}{\partial z}\left[K(\theta)\left(\frac{\partial h}{\partial z}+1\right)\right]-S(z, t)
$$

式中, $\theta$ 为土壤体积含水量 $\left(\mathrm{cm}^{3} / \mathrm{cm}^{3}\right) ; h$ 为负压水头 $(\mathrm{cm}) ; K(\theta)$ 为非饱和渗透系数 $(\mathrm{cm} / \mathrm{d}) ; z$ 为垂直方向土 壤深度 $(\mathrm{cm}) ; S(z, t)$ 为根系吸水速率 $\left(\mathrm{cm}^{3} /\left(\mathrm{cm}^{3} \cdot \mathrm{d}\right)\right)$.

非饱和渗透系数 $K(\theta)$ 和土壤水分特征曲线的经验公式采用 van-Genuchten 模型描述 ${ }^{[34]}$ :

$$
\begin{gathered}
\theta(h)= \begin{cases}\theta_{\mathrm{r}}+\frac{\theta_{\mathrm{s}}-\theta_{\mathrm{r}}}{\left[1+|\alpha h|^{n}\right]^{m}} & h<0 \\
\theta_{\mathrm{s}} & h \geqslant 0\end{cases} \\
K(\theta)=K_{\mathrm{s}} S_{\mathrm{e}}^{1 / 2}\left[1-\left(1-S_{\mathrm{e}}^{1 / m}\right)^{m}\right]^{2} \\
S_{\mathrm{e}}=\frac{\theta-\theta_{\mathrm{r}}}{\theta_{\mathrm{s}}-\theta_{\mathrm{r}}}
\end{gathered}
$$

式中, $n 、 m$ 为经验拟合参数, 其中 $m=1-1 / n ; S_{\mathrm{e}}$ 为土壤有效水含量.

根系吸水速率 $S(z, t)$, 即植物根系在单位时间内从单位体积土壤中吸收的水分体积, 通过根系吸水模 块进行数值解析, 采用 Feddes 模型 ${ }^{[33]}$ :

$$
S(z, t)=\alpha(h) \gamma(z) T_{\mathrm{p}}
$$

式中, $T_{\mathrm{p}}$ 为潜在蒸腾速率 $(\mathrm{cm} / \mathrm{d}) ; r(z)$ 为根系吸水分布函数 $\left(\mathrm{cm}^{-1}\right) ; \alpha(h)$ 为水分胁迫函数 $(0 \leqslant \alpha \leqslant 1)$, 采用 S-Shaped 模型描述 ${ }^{[34]}$ :

$$
\alpha(h)=\frac{1}{1+\left(h / h_{50}\right)^{p}}
$$

蒸散发模块可数值解析蒸散发 $E T_{\mathrm{p}}$, 利用气象条件根据 FAO 推荐的 Penman-Monteith 方程确定, 潜在蒸 腾 $T_{\mathrm{p}}$ 和潜在蒸发 $E_{\mathrm{p}}$ 根据 Beer's 公式, 利用叶面积指数 $L A I$ 和消光系数 $k$ 进行分割 ${ }^{[35]}$. 消光系数与植被种类、 群体结构和叶面积指数大小有关, 从萌芽期到成熟期逐渐减小, 本文消光系数取值根据贾庆宇等测定的湿 
地芦苇群落不同生长阶段 $k$ 值结果 ${ }^{[36]}$, 取其平均值 0.39 , 这与已有文献中 ${ }^{[37-39]}$ 关于湿地草甸区消光系数的 取值范围 0.25 0.78 相吻合, 适用于鄱阳湖湿地芦苇群落的蒸散分割.

2.2.2 边界条件和初始条件 上边界选在地表, 给定大气边界, 接受降水入渗和蒸散发消耗. 下边界选模拟 期内最深潜水位以下, 即地面以下 $8 \mathrm{~m}$, 给定变压力水头边界. 初始条件给定模拟初期土壤含水量的垂向 分布.

2.2.3 输入数据 上边界的降雨量和下边界的地下水压力水头数据(图 4、5) 通过监测系统自动获取, 上边界的 蒸散发量利用模型根据太阳辐射、气温、湿度等气象数据(图 5)、植物生长数据和根系吸水数据可计算得到.

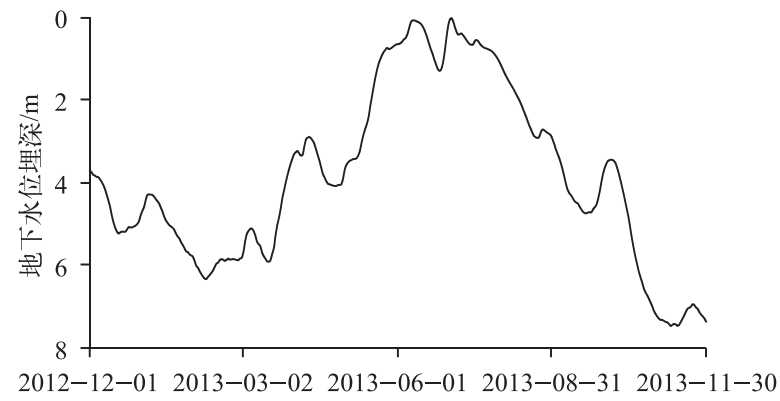

图 4 地下水位埋深日变化

Fig.4 Diurnal variation of the groundwater depth
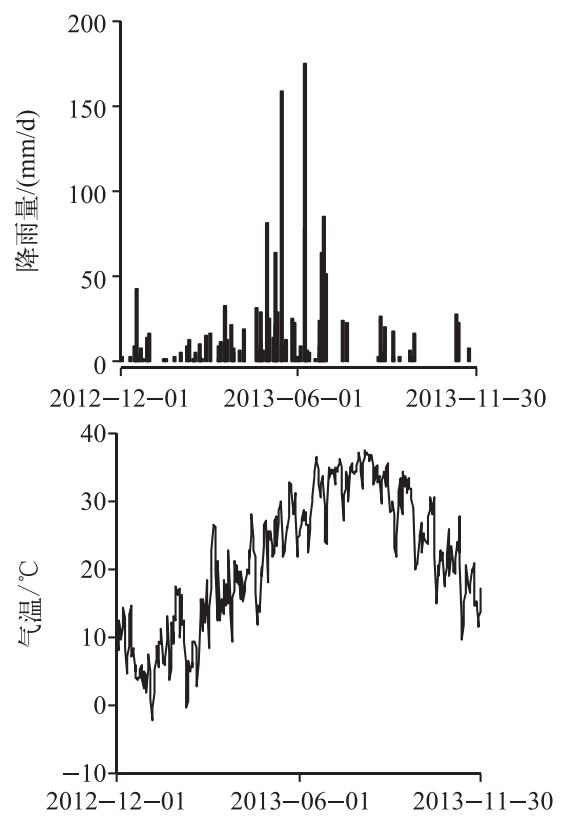

2012 年 12 月 -2013 年 11 月期间, 年降 雨量为 $1718 \mathrm{~mm}$, 主要集中在 $4-6$ 月,占年总 量的 $66 \%$; 年太阳辐射总量为 $3836.92 \mathrm{MJ} / \mathrm{m}^{2}$, 7-8 月太阳辐射量最大, 达到 $979.11 \mathrm{MJ} / \mathrm{m}^{2}$; 气温年内呈单峰型变化, 日平均气温的最高值 出现在 7 月, 最低值出现在 1 月; 湿度在 $54.3 \% \sim 98.7 \%$ 范围内变化.

植物生长数据包括反照率 (默认值 0.23 )、 叶面积指数和平均株高, 根据野外测定值输 人, 叶面积指数和平均株高分别在 $1.62 \sim 5.37$ 和 39 $196 \mathrm{~cm}$ 范围内, 7-8 月达到最大, 12 月至次年 2 月最小.
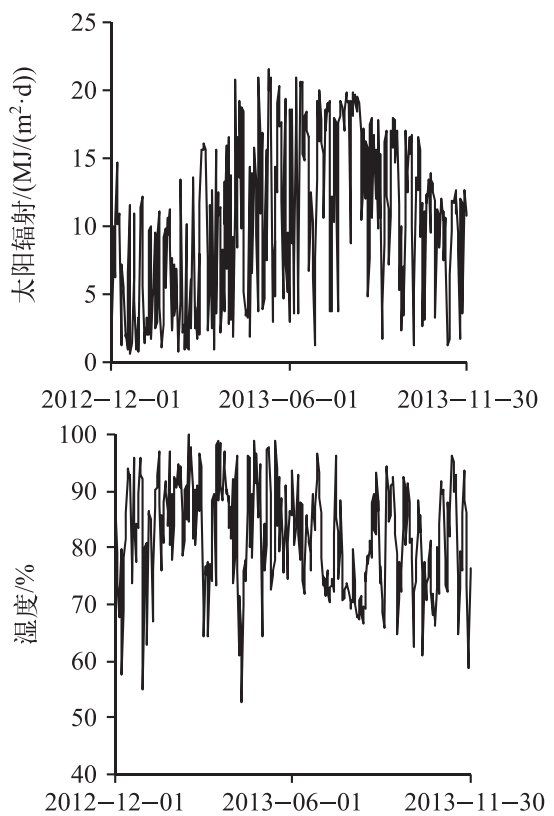

图 5 降雨、太阳辐射、气温和湿度等气象数据的日变化

Fig.5 Diurnal variations of rainfall, solar radiation, temperature and humidity

根系吸水深度为 $80 \mathrm{~cm}$, 总根长 $L_{\mathrm{R}}$ 为 $6217 \mathrm{~cm}$, 根系吸水密度函数 $r(z)$ 根据不同深度的根系分布密度采 用分段函数描述为:

$$
r(z)=\left\{\begin{array}{cc}
317 / L_{\mathrm{R}} & 0 \mathrm{~cm} \leqslant z \leqslant 10 \mathrm{~cm} \\
85 / L_{\mathrm{R}} & 10 \mathrm{~cm} \leqslant z \leqslant 40 \mathrm{~cm} \\
12.4 / L_{\mathrm{R}} & 40 \mathrm{~cm} \leqslant z \leqslant 80 \mathrm{~cm}
\end{array}\right.
$$


2.2.4 模型参数 模型中的土壤水分动力学参数包括土壤水分特征曲线 van-Genuchten 模型中的 $\theta_{\mathrm{r}} 、 \theta_{\mathrm{s}} 、 \alpha 、 n$ 以及 $K_{\mathrm{s}}$. 本文首先在野外间隔 $20 \mathrm{~cm}$ 分层采集原状土 $(0 \sim 120 \mathrm{~cm})$, 室内进行土壤机械组成分析和土壤水分 脱湿实验, 结果表明根系层土壤质地均为粉砂土 (表 1), 但脱湿条件下 $0 \sim 20 \mathrm{~cm}$ 和 $20 \sim 80 \mathrm{~cm}$ 深度处的土壤 水分特征曲线形态存在明显差异 (图 6), 说明土壤表层和根系层深部的土壤水分动力学参数存在较强的垂 向异质性, 因此本文将根系层土壤分成 $0 \sim 20$ 和 $20 \sim 80 \mathrm{~cm}$ 两层,根系层以下 $80 \sim 800 \mathrm{~cm}$ 分为第 3 层.

表 1 土壤机械组成和容重

Tab.1 Soil texture composition and bulk density data

\begin{tabular}{ccccccc}
\hline 土壤分层 & 土壤深度 $/ \mathrm{cm}$ & 砂 $/ \%$ & 粉砂 $/ \%$ & 䵗土 $/ \%$ & 干容重 $/\left(\mathrm{g} / \mathrm{cm}^{3}\right)$ & 土壤质地 \\
\hline 1 & $0 \sim 20$ & 13.6 & 76.0 & 11.4 & 1.35 & 粉砂土 \\
2 & $20 \sim 80$ & 23.1 & 64.3 & 12.5 & 1.24 & 粉砂土 \\
3 & $80 \sim 800$ & 17.7 & 68.4 & 13.9 & 1.40 & 粉砂土 \\
\hline
\end{tabular}

土壤水分动力学参数初始值根据土壤机械 组成利用 HYDRUS-1D 自带的人工神经网络模 型获取 ${ }^{[40]}, l$ 为孔隙弯曲度 $(\text { 一般取 } 0.5)^{[41]}$ (表 2 ). 根系吸水参数 $h_{50}$ 和 $p$ 的取值依据已有文 献 ${ }^{[42]}$ 分别赋予 $-2456 \mathrm{~cm}$ 和 3 . 上述估计的模型 参数初始值, 依据野外实测的土壤含水量数据, 在模型率定阶段采用 Marquardt-Levenberg 反演 法展开进一步优化 ${ }^{[41]}$, 实现模拟结果最大程度 地接近实测结果, 从而确定试验区土壤水分动 力学参数及根系吸水参数.

在模型率定以前, 先进行参数敏感性分析, 辨明影响土壤水分动态变化的敏感参数, 指导 重点调参, 本文应用单因素敏感性分析法, 逐一 将每个参数分别增加和减少 $10 \%$, 计算敏感系

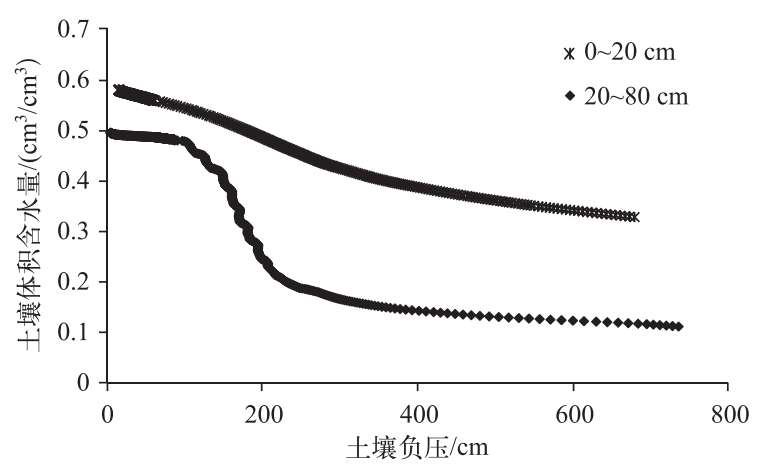

图 6 脱湿条件下土壤水分特征曲线

Fig.6 The soil water characteristic curves in dehumidification experiments 数 $A_{i}($ 公式 $(9))$, 敏感系数的绝对值越大, 表示对应的输人参数 $x_{i}$ 对目标函数 $y$ 的影响程度越大 ${ }^{[43]}$.

表 2 土壤水分动力学参数初始值

Tab.2 The initial values of soil hydrodynamic parameters

\begin{tabular}{ccccccc}
\hline 土壤深度 $/ \mathrm{cm}$ & $\theta_{\mathrm{r}} /\left(\mathrm{cm}^{3} / \mathrm{cm}^{3}\right)$ & $\theta_{\mathrm{s}} /\left(\mathrm{cm}^{3} / \mathrm{cm}^{3}\right)$ & $\alpha / \mathrm{cm}^{-1}$ & $n$ & $K_{\mathrm{s}} /(\mathrm{cm} / \mathrm{d})$ & $l$ \\
\hline $0 \sim 20$ & 0.059 & 0.457 & 0.005 & 1.689 & 28.52 & 0.5 \\
$20 \sim 80$ & 0.056 & 0.431 & 0.004 & 1.702 & 28.20 & 0.5 \\
$80 \sim 800$ & 0.061 & 0.440 & 0.005 & 1.692 & 23.35 & 0.5 \\
\hline
\end{tabular}

$$
A_{i}=\frac{\Delta y / y}{\Delta x_{i} / x_{i}}
$$

式中, $\Delta y / y$ 为目标函数值变化百分比; $\Delta x_{i} / x_{i}$ 是第 $i$ 个参数值变化百分比.

本文分析 3 项目标函数, 分别为 $10 、 50$ 和 $100 \mathrm{~cm}$ 土层深度的土壤体积含水量 $\theta_{10} 、 \theta_{50}$ 和 $\theta_{100}$, 考虑 20 个 模型输人参数 $x_{i}($ 表 3$)$,进行参数敏感性分析, 以此提高模型率定的效率及精度.

\section{3 模型率定}

模型率定期为 2012 年 12 月 1 日-2013 年 11 月 30 日, 时间步长为天. 利用实测的 $10 、 50 、 100 \mathrm{~cm}$ 处的 土壤含水量数据, 对初始模型参数进行优化 ${ }^{[24]}$. 拟合效果采用均方根误差 $(R M S E)$ 、相对误差 $(R E)$ 和相关 系数 $(R)$ 定量评价: 
表 3 敏感性分析的输人参数

Tab.3 The input parameters for sensitivity analysis

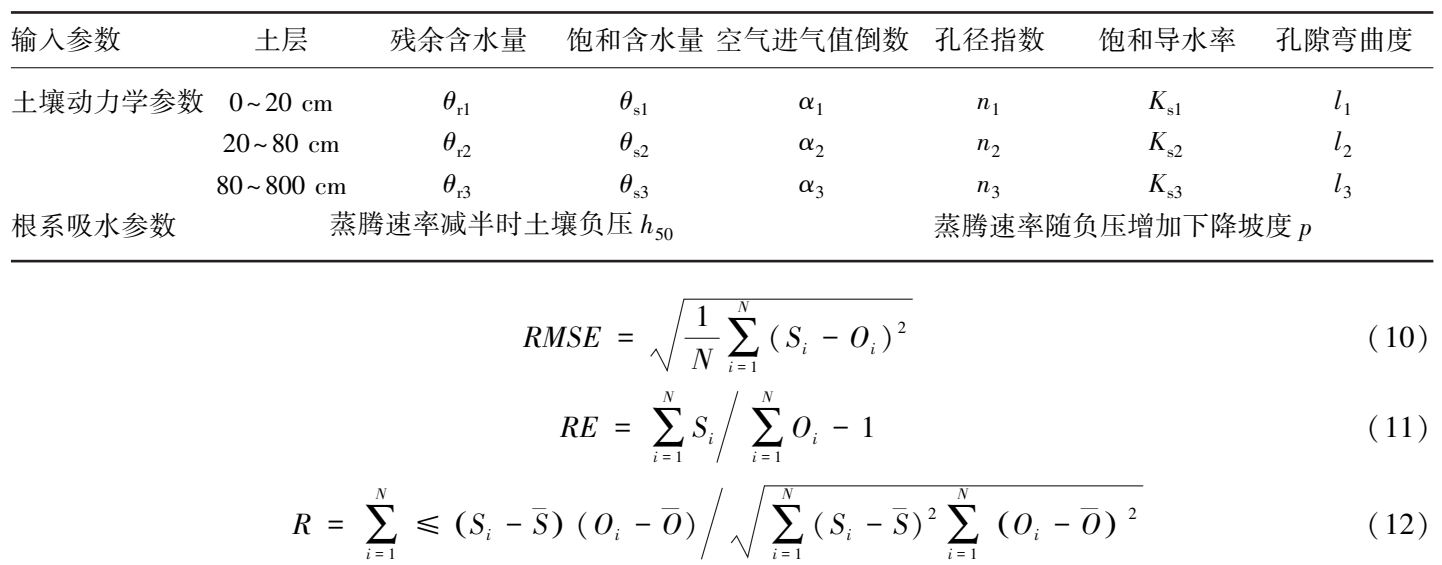

式中, $S_{i}$ 和 $O_{i}$ 分别代表第 $i$ 个时段的模拟值和观测值, $\bar{S}$ 和 $\bar{O}$ 分别为模拟值和观测值的平均值, $N$ 为总模拟 时段数.

\section{3 结果与分析}

\section{1 土壤含水量的参数敏感性分析}

按敏感系数的绝对值由大到小依次排序, 列出了土壤含水量 $\theta_{10} 、 \theta_{50} 、 \theta_{100}$ 的 10 个输人参数 (表 4 , 其余参 数敏感系数绝对值小于 0.05$)$.

表 4 土壤含水量的敏感输人参数*

Tab.4 Sensitive input soil parameters of soil moisture content

\begin{tabular}{cccccr}
\hline$\theta_{10}$ 的输人参数 & $\theta_{10}$ 的敏感系数 & $\theta_{50}$ 的输人参数 & $\theta_{50}$ 的敏感系数 & $\theta_{100}$ 的输人参数 & $\theta_{100}$ 的敏感系数 \\
\hline$n_{1}$ & -1.47 & $n_{2}$ & -2.22 & $n_{3}$ & -1.44 \\
$\theta_{\mathrm{s} 1}$ & 0.93 & $\theta_{\mathrm{s} 2}$ & 0.49 & $\theta_{\mathrm{s} 3}$ & 0.71 \\
$\alpha_{2}$ & 0.46 & $\alpha_{2}$ & -0.45 & $\alpha_{3}$ & -0.57 \\
$n_{2}$ & -0.38 & $n_{3}$ & 0.37 & $K_{\mathrm{s} 3}$ & 0.21 \\
$\alpha_{1}$ & -0.19 & $\theta_{\mathrm{s} 1}$ & -0.19 & $n_{2}$ & 0.11 \\
$K_{\mathrm{s} 2}$ & -0.10 & $n_{1}$ & -0.18 & $\alpha_{2}$ & 0.07 \\
$\theta_{\mathrm{s} 2}$ & -0.08 & $\theta_{\mathrm{r} 2}$ & 0.09 & $\theta_{\mathrm{r} 3}$ & 0.07 \\
$n_{3}$ & 0.04 & $\alpha_{3}$ & -0.08 & $\theta_{\mathrm{s} 2}$ & -0.03 \\
$\theta_{1}$ & 0.03 & $h_{50}$ & -0.07 & $h_{50}$ & -0.02 \\
$h_{50}$ & -0.03 & $\theta_{\mathrm{s} 3}$ & -0.07 & $\theta_{\mathrm{s} 1}$ & -0.01 \\
\hline
\end{tabular}

若敏感系数 $>0.2$ 时, 认为该 $x_{i}$ 是土壤含水量的敏感参数 ${ }^{[43]}$. 表层土壤含水量 $\theta_{10}$ 的敏感参数包括 $n_{1}$ 、 $\theta_{\mathrm{s} 1} 、 \alpha_{2}$ 和 $n_{2}$, 其中 $n_{1}$ 是最主要的影响参数, 其次为 $\theta_{s 1} 、 \alpha_{2}$ 和 $n_{2}$, 当上述参数变化 $10 \%$ 时, 土壤含水量相应变幅 分别为 $14.7 \% 、 9.3 \% 、 4.6 \%$ 和 $3.8 \%$; 根系层中部土壤含水量 $\theta_{50}$ 的敏感参数按影响程度由大到小依次为 $n_{2}$ 、 $\theta_{\mathrm{s} 2} 、 \alpha_{2}$ 和 $n_{3}$, 当参数变化 $10 \%$, 土壤含水量分别变化 $22.2 \% 、 4.9 \% 、 4.5 \%$ 和 $3.7 \%$; 根系层底部土壤含水量 $\theta_{100}$ 的敏感参数包括 $n_{3} 、 \theta_{\mathrm{s} 3} 、 \alpha_{3}$ 和 $K_{\mathrm{s} 3}$, 各参数变化 $10 \%$ 时, 土壤含水量分别变化 $14.4 \% 、 7.1 \% 、 5.7 \%$ 和 $2.1 \%$.

总体来说, 土壤含水量对根系吸水参数 $\left(p\right.$ 和 $h_{50}$ ) 变化的响应并不敏感, 当根系吸水参数变化 $10 \%$ 时, 土 壤含水量的变幅小于 $0.7 \%$, 土壤水分动力学参数是其主要影响参数, 不同深度处的土壤含水量 $\theta$ 受 $n$ 的影 响最大, 其次是 $\theta_{\mathrm{s}} 、 \alpha$ 和 $K_{\mathrm{s}}$. 因此, 在模型率定阶段, 优先着重对 $n 、 \theta_{\mathrm{s}} 、 \alpha$ 和 $K_{\mathrm{s}}$ 进行调参.

\section{2 模型率定结果}

模型率定后的土壤水分动力学参数见表 5 , 试验区以粉砂土为主, 与美国农业部给出的相应土质参数参 
考范围基本一致 ${ }^{[44]}$.

表 5 模型率定后的土壤水分动力学参数取值

Tab.5 Calibrated values of soil hydraulic parameters

\begin{tabular}{ccccccc}
\hline 土壤深度 $/ \mathrm{cm}$ & $\theta_{\mathrm{r}} /\left(\mathrm{cm}^{3} / \mathrm{cm}^{3}\right)$ & $\theta_{\mathrm{s}} /\left(\mathrm{cm}^{3} / \mathrm{cm}^{3}\right)$ & $\alpha / \mathrm{cm}^{-1}$ & $N$ & $K_{\mathrm{s}} /(\mathrm{cm} / \mathrm{d})$ & $L$ \\
\hline $0 \sim 20$ & 0.034 & 0.46 & 0.008 & 1.08 & 102 & 0.5 \\
$20 \sim 80$ & 0.034 & 0.46 & 0.005 & 1.14 & 80 & 0.5 \\
$80 \sim 800$ & 0.034 & 0.46 & 0.009 & 1.08 & 45 & 0.5 \\
\hline
\end{tabular}

研究区土壤含水量的变化范围为 $0.30 \sim 0.48$, 模型率定时段内土壤含水量的模拟值与实测值的变化趋 势一致 (图 7), 实测值与模拟值的差值不足 0.055 . 该差异主要是由模型输人数据的不确定性造成的. 此外, 观测数据也会带有一定的误差. 总体说来, 模拟的土壤含水量能很好地体现实测含水量的变化过程, 尤其是 模拟出了秋季退水后土壤含水量的缓慢下降, 再现了土壤水分的季节动态. 个别时段波动幅度较大主要是 因为模型假设降水落到地面后很快进人土壤, 以垂向运移为主, 因此土壤含水量模拟值对日降水的响应尤 为敏感, 表现出明显的波动性, 而实际土壤水分由于植物冠层的截留及地表枯枝落叶层的滞留作用, 土壤水 分变化较为平缓.

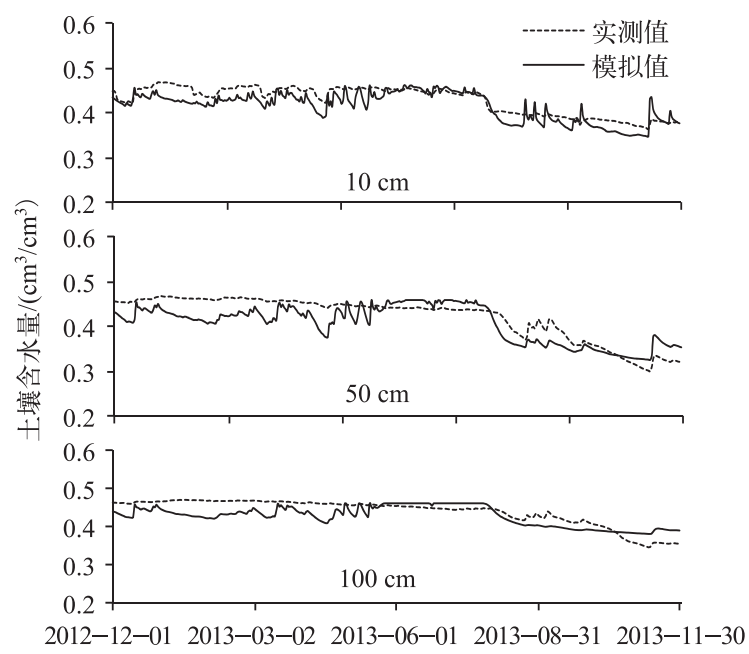

图 7 土壤含水量模拟值与实测值的对比

Fig.7 Comparison of observed and simulated soil water contents

采用不同的统计指标对模型的模拟精度进行评价 (表 6), $R M S E$ 的变化范围为 $0.03 \sim 0.04 \mathrm{~cm}^{3} / \mathrm{cm}^{3}, R E$ 的变化范围为 $0 \sim 2 \%$, 相关系数 $R$ 的变化范围为 $0.82 \sim 0.92$, 结果显示率定期土壤含水量的模拟值与实测值 的拟合效果良好,模型对长序列土壤含水量变化具有很好的模拟效果.

表 6 土壤含水量模拟值与实测值拟合效果统计值

Tab.6 Assessment of observed and simulated soil water content

\begin{tabular}{|c|c|c|c|c|}
\hline \multirow{2}{*}{ 验证目标 } & & \multicolumn{3}{|c|}{ 率定期 } \\
\hline & & $R M S E /\left(\mathrm{cm}^{3} / \mathrm{cm}^{3}\right)$ & $R E$ & $R$ \\
\hline 表层土壤含水量 & $\theta_{10}$ & 0.03 & -0.00 & 0.82 \\
\hline 根系层中部土壤含水量 & $\theta_{50}$ & 0.03 & -0.02 & 0.84 \\
\hline 根系层底部土壤含水量 & $\theta_{100}$ & 0.04 & -0.02 & 0.92 \\
\hline
\end{tabular}




\subsection{GSPAC 系统界面水分运移规律分析}

利用构建的鄱阳湖典型湿地 GSPAC 系统水分垂向运移模型, 定量分析 GSPAC 系统界面水分通量的组 成和季节变化(图 8), 包括 $R_{\mathrm{in}} 、 E_{\mathrm{a}} 、 T_{\mathrm{a}} 、 G$ 和 $D$ 在日、月尺度的变化值及其占年总量的比例(表 7).

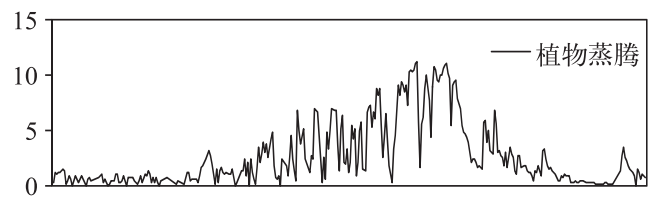

(a) 大气一植物界面水分通量

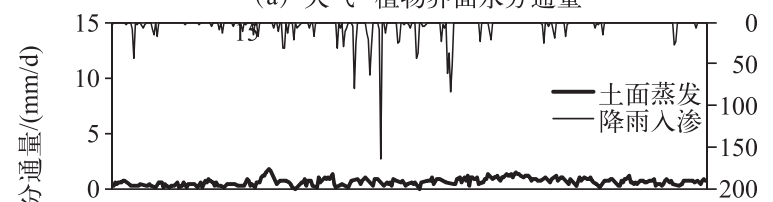

（b）大气一土壤界面水分通量
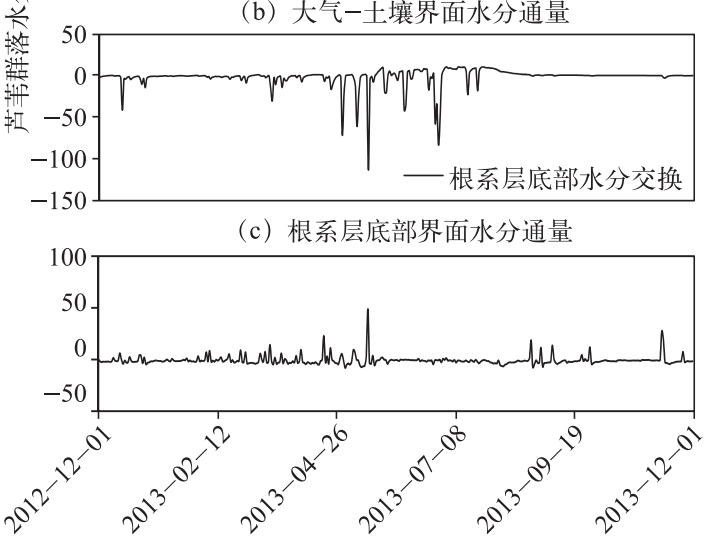

(d) 根系层土壤水分变化

图 8 湿地 GSPAC 界面的日水分通量变化

Fig. 8 Diurnal variation of water fluxes in wetland GSPAC interfaces

(1)大气一植物界面水分通量

大气一植物界面的水分通量为植物蒸腾. 鄱阳湖湿地蒸散发包括土面蒸发和植物蒸腾, 以植物蒸腾为 主, 年蒸腾总量为 $926 \mathrm{~mm}$, 是土面蒸发 $(176 \mathrm{~mm})$ 的 5.3 倍. 植物蒸腾年内变化呈单峰型, 与芦苇群落生长过 程保持一致, 峰值出现在芦苇群落生长旺盛期 7-8 月, 该时段累积蒸腾量为 $430 \mathrm{~mm}$, 占年总量的 47\%, 芦苇 群落枯萎期 $12-2$ 月蒸腾量最小, 月蒸腾量均小于 $20 \mathrm{~mm} /$ 月.

(2) 大气一土壤界面水分通量

大气一土壤界面的水分通量为降雨人渗和土面蒸发. 年降雨量 $(1718 \mathrm{~mm})$ 部分因地面径流消耗, 其余均 人渗, 年降雨人渗总量为 $1450 \mathrm{~mm}$, 有明显的季节性差异, 雨季 4-6月的降水人渗量为 $937 \mathrm{~mm}$, 占年总量的 $65 \%$. 土面蒸发量全年仅为 $176 \mathrm{~mm}$, 季节性差异并不明显, 夏季 7-8 月蒸发量较大 $(25 \sim 28 \mathrm{~mm} /$ 月), 冬季 12 至次年 2 月蒸发量较小 ( $6 \sim 9 \mathrm{~mm} /$ 月).

(3) 根系层底部界面水分通量

根系层底部界面存在根系层土壤与根系层以下深层土壤之间的水分交换,负值代表根系层水分深层渗 漏, 补给深层土壤水, 正值代表深层土壤水对根系层土壤的向上补给. 鄱阳湖湿地芦苇群落根系层底部界面 的水分向上运移的年补给量为 $609 \mathrm{~mm}$, 主要发生在蒸散发作用强烈和地下水浅埋的时段,如气候炎热、植物 生长旺盛且高水位的 6-8 月,该时段的累积向上补给总量为 $465 \mathrm{~mm}$, 占年总补给量的 76\%. 而根系层水分 的年深层渗漏总量为 $1053 \mathrm{~mm}$, 主要发生在强降雨的 4-6月, 该时段的累积渗漏总量 $(762 \mathrm{~mm})$ 占全年渗漏 总量的 $73 \%$. 
(4) 根系层土壤水分变化

根系层土壤受上下界面水分交换过程的影响,储水量不断变化,负值表示根系层土壤水分消耗,正值表 示水分累积. 根系层土壤水分在 2、5、11 月(14.3 20.8 mm) 明显累积, 4 月略有增加 $(8.2 \mathrm{~mm}$ ), 其余月份水 分均消耗 $(-8.6 \sim-21.4 \mathrm{~mm})$, 处于亏损状态, 尤其是 7 月 $(-29.5 \mathrm{~mm})$ 和 8 月 $(-42.2 \mathrm{~mm})$.

表 7 GSPAC 系统界面的月水分通量变化

Tab.7 Monthly variation of water fluxes in GSPAC system

\begin{tabular}{|c|c|c|c|c|c|c|c|c|c|c|c|}
\hline \multirow{2}{*}{ 水文年 } & \multirow{2}{*}{ 月份 } & \multicolumn{5}{|c|}{ 月水分通量/ $(\mathrm{mm} /$ 月 $)$} & \multicolumn{5}{|c|}{ 月水分通量比例/\% } \\
\hline & & $R_{\text {in }}$ & $G$ & $E_{\text {a }}$ & $T_{\mathrm{a}}$ & $D$ & $R_{\text {in }}$ & $G$ & $E_{\mathrm{a}}$ & $T_{\mathrm{a}}$ & $D$ \\
\hline 2012 & 12 & 108 & 3 & 8 & 17 & 101 & 7 & 0 & 5 & 2 & 10 \\
\hline \multirow[t]{11}{*}{2013} & 1 & 11 & 4 & 9 & 18 & 5 & 1 & 1 & 5 & 2 & 0 \\
\hline & 2 & 58 & 1 & 6 & 8 & 32 & 4 & 0 & 3 & 1 & 3 \\
\hline & 3 & 143 & 7 & 16 & 39 & 106 & 10 & 1 & 9 & 4 & 10 \\
\hline & 4 & 215 & 16 & 11 & 58 & 153 & 15 & 3 & 6 & 6 & 15 \\
\hline & 5 & 356 & 60 & 12 & 116 & 271 & 25 & 10 & 7 & 13 & 26 \\
\hline & 6 & 366 & 106 & 10 & 133 & 338 & 25 & 17 & 6 & 14 & 32 \\
\hline & 7 & 44 & 269 & 25 & 277 & 41 & 3 & 44 & 14 & 30 & 4 \\
\hline & 8 & 49 & 90 & 28 & 153 & 0 & 3 & 15 & 16 & 17 & 0 \\
\hline & 9 & 43 & 24 & 16 & 60 & 0 & 3 & 4 & 9 & 6 & 0 \\
\hline & 10 & 0 & 18 & 20 & 20 & 0 & 0 & 3 & 11 & 2 & 0 \\
\hline & 11 & 57 & 11 & 15 & 27 & 6 & 4 & 2 & 9 & 3 & 1 \\
\hline
\end{tabular}

\section{4 土壤水分补排过程分析}

湖泊水情的改变是引起湿地土壤水分补排过程动态变化的主导因子, 根据鄱阳湖近 30 年的水位变化 规律, 将 12 月至翌年 3 月划分为枯水期, 4- 6 月为涨水期, 7-9 月为丰水期, 10-11 月为退水期 ${ }^{[45]}$. 本文 采用 2012 年 12 月- 2013 年 11 月的模型水均衡计算结果 (表 8 ) 及各补给项和排泄项占不同时期的补给总 量和排泄总量的比例 (图 9), 定量分析鄱阳湖枯、涨、丰、退水期 4 个时段的湿地土壤水分补排过程.

整体来看, 鄱阳湖湿地根系层土壤水分主要补给来源为降水和深层土壤水分的向上补给,其中降水是 主要补给源, 年降水入渗量 $(1450 \mathrm{~mm})$ 是根系层以下深层土壤水补给量 $(609 \mathrm{~mm})$ 的 2.4 倍, 蒸散发和渗漏 是根系层土壤水的主要排泄途径, 根系层土壤水量平衡以亏损为主, 年亏损量为 $87 \mathrm{~mm}$. 湿地水分的补排关 系受气象因素、地下水位高低以及植物生长的影响, 表现出显著的季节性动态, 具体分析如下:

表 8 不同水文时段根系层水均衡情况

Tab.8 Water balance of root zones in different water level stages

\begin{tabular}{|c|c|c|c|c|c|c|c|}
\hline \multirow{2}{*}{ 水文时段 } & \multicolumn{2}{|c|}{ 补给来源 } & \multicolumn{3}{|c|}{ 排泄途径 } & \multirow{2}{*}{$\begin{array}{c}\Delta W / \\
\mathrm{mm}\end{array}$} & \multirow{2}{*}{$\begin{array}{c}A E^{*} \\
\mathrm{~mm}\end{array}$} \\
\hline & $R_{\text {in }} / \mathrm{mm}$ & $G / \mathrm{mm}$ & $E_{\mathrm{a}} / \mathrm{mm}$ & $T_{\mathrm{a}} / \mathrm{mm}$ & $D / \mathrm{mm}$ & & \\
\hline 枯水期( $12-3$ 月) & 320 & 15 & -39 & -82 & -244 & -27 & 3 \\
\hline 涨水期 $(4-6$ 月) & 937 & 182 & -33 & -307 & -762 & 20 & 4 \\
\hline 丰水期 (7-9 月) & 136 & 383 & -69 & -490 & -41 & -76 & 5 \\
\hline 退水期 (10-11月) & 57 & 29 & -35 & -47 & -6 & -4 & -3 \\
\hline 年总量 & 1450 & 609 & -176 & -926 & -1053 & -87 & 9 \\
\hline
\end{tabular}

$A E^{*}$ 表示水量平衡绝对误差.

在枯水期 (12-3 月), 地下水位埋深大于 $6 \mathrm{~m}$, 根系层以下水分的向上补给可忽略, 大气降水为唯一补 给来源, 补给量为 $320 \mathrm{~mm}$, 占所有补给来源的 $95 \%$. 该时段植物枯萎死亡, 蒸散发作用微弱, 植物蒸腾和土 面蒸发分别占排泄总量的 $22 \%$ 和 $11 \%$. 深层渗漏为根系层土壤水分主要排泄途径, 排泄量为 $244 \mathrm{~mm}$, 占总 

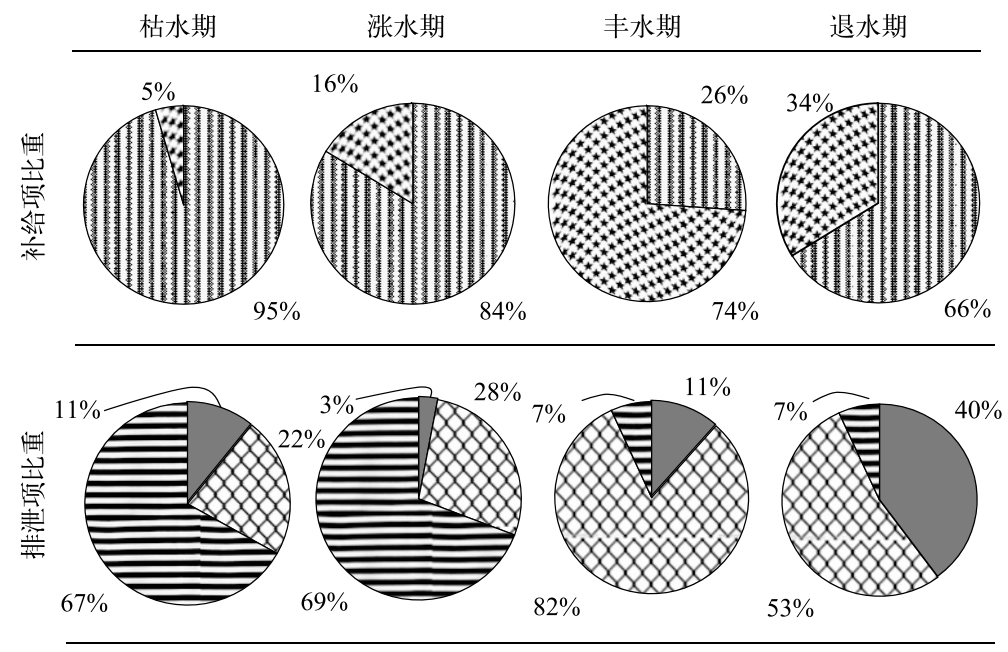

国降雨入渗 $* * \star *$ 深层土壤水补给 植物蒸腾 $\square$ 土面蒸发

图 9 不同水文时段根系层土壤水的补排关系

Fig.9 Supply and drainage relationships of root zone in different water level stages

排泄量的 $67 \%$. 该时段土壤水分亏损,土壤水储量减少 $27 \mathrm{~mm}$.

在涨水期 (4-6月), 正值雨季, 降水是湿地土壤水分的主要补给来源, 降水人渗量为 $937 \mathrm{~mm}$, 占总补给 来源的 $84 \%$. 由于地下水位的上升 $(2 \sim 6 \mathrm{~m})$, 深层土壤水对根系层土壤存在明显的向上补给, 补给量为 182 $\mathrm{mm}$, 占补给总量的 $16 \%$. 该阶段根系层土壤水分排泄以根系层水分渗漏为主, 渗漏量为 $762 \mathrm{~mm}$, 占排泄总 量的 69\%. 该时段处于植物生长初期, 蒸腾耗水较小, 加之雨期土面蒸发微弱, 蒸散发仅占总排泄量的 $31 \%$. 该时段土壤水分积累, 根系层土壤水储量增加 $20 \mathrm{~mm}$.

在丰水期 (7-9 月), 鄱阳湖集中降雨期基本结束, 且地下水位大幅上升, 深层土壤水补给成为根系层 土壤水分的主要补给来源, 补给量为 $383 \mathrm{~mm}$, 占补给总量的 $74 \%$. 该时段是鄱阳湖全年气温最高、日照最强 的时期, 加之植物处于生长旺盛期, 植物蒸腾耗水是土壤水分的主要排泄途径, 蒸腾量为 $490 \mathrm{~mm}$, 占总排泄 量的 $82 \%$; 而土面蒸发和根系层水分渗漏较少, 分别占总排泄量的 $11 \%$ 和 7\%. 该时段根系层土壤水储量亏 损 $76 \mathrm{~mm}$.

在退水期 (10-11 月), 地下水位下降至 $4 \mathrm{~m}$ 以下, 根系层以下水分对根系层土壤水的补给较丰水期减 少,占补给总量的 $34 \%$, 而降水人渗成为土壤水分最主要的补给来源, 占补给总量的 $66 \%$. 同时,蒸散发作用 仍是该时段土壤水分的主要排泄途径, 占总排泄的 $93 \%$. 该时段根系层土壤水量平衡基本维持稳定, 土壤水 分储量仅减小 $4 \mathrm{~mm}$.

\section{4 讨论}

湿地生态系统以水分作为物质和能量迁移转换的主要媒介, 其运移过程不仅影响土壤物化性质及营养 环境, 还决定湿地物种的萌发、生长与演替, 主导了湿地生态系统的形成与演变, 是湿地生态水文研究的热 点问题. 湿地位于水陆过渡带, 水分运移过程的影响因素众多, 作用机理复杂, 刘昌明院士曾指出, 研究水分 转化机制必须从水分流通的各个界面人手 ${ }^{[46]}$, 然而, 以往国内外学者主要研究湿地关键水文要素的时空变 化, 从界面过程角度探求湿地水分在地下水含水层-土壤-植物-大气连续体的动态变化和补排关系仍鲜见 报道.

本文运用数值模拟法探究了鄱阳湖典型洲滩湿地生态系统水分在不同界面的传输过程, 发现鄱阳湖湿 地界面水分通量具有明显的季节性差异, 其中大气一土壤界面的降雨人渗量及根系层底部界面的水分渗漏 量均对降雨变化的响应十分敏感, 主要集中在 4-6月, 这与其他湿地和农田系统水分人渗的研究结果相一 
致, 降雨人渗量和深层渗漏量与降雨量高度关联, 随降雨量的增加而呈现升高趋势 ${ }^{[30,47-50]}$. 大气-植物界面 的植物蒸腾量峰值出现在 7-8 月, 主要原因是该时段植物生长旺盛且气候炎热, 国内外学者对植物蒸腾研 究过程中也发现类似规律, 植物蒸腾明显受植物生长进程和气候条件的影响. 森林系统中, 没有明显的生长 季和非生长季之分, 月蒸腾量变化趋势受气温影响, 变幅较小 ${ }^{[51-54]}$; 而湿地系统与之不同, 植被季相差异显 著, 在植被萌发、成熟、衰亡各阶段, 植物蒸腾变幅明显 ${ }^{[55-58]}$, 例如三江平原典型沼泽湿地草甸植物蒸腾量从 5 月起随着植被的萌发生长而不断增加, $7-8$ 月气候炎热且植被成熟时段蒸腾量最大, 9 月植被进人调萎 期, 蒸腾量不断下降; 农田系统的植物蒸腾也明显与气候条件和作物生长有关 ${ }^{[59-60]}$. 此外, 以往湿地水分补 给来源普遍考虑降水和地表水, 湿地地下界面水分交换过程由于观测困难而认识较少, 在模拟研究中也往 往概化为自由排水边界, 不考虑深层土壤水的向上补给, 但实际上, 当表层土壤缺水且地下水浅埋时深层土 壤水是表层土壤水分的主要补给来源之一 ${ }^{[3-5,61]}$. 如我国西北干旱-半干旱区的塔里木河和黑河下游湿地的 地下水位下降直接减少了对包气带土壤水分的补给 ${ }^{[62-63]}$, 本研究也发现鄱阳湖湿地芦苇群落区 7-9 月的 根系层土壤水分补给来源以深层土壤水为主, 达到 $383 \mathrm{~mm}$, 是降水补给的 2.8 倍, 全年根系层以下的深层土 壤水补给量达到 $609 \mathrm{~mm}$, 占年水分补给总量的 $30 \%$. 基于以上, 可知湿地土壤水分主要补给来源( 降雨人渗 和深层土壤水) 和排泄途径 (植物蒸腾和水分渗漏) 季节性变化的主导影响因子, 结合近几年鄱阳湖湿地气 候、水位波动情势的变化, 可以预测湿地水分补排关系的变化, 如湖水位的持续下降将显著减少深层土壤水 向上补给, 降雨量的减少则直接削减降雨人渗补给, 导致根区土壤水分缺失, 可能造成湿生植物向旱生植物 演替,出现湿地萎缩,本文为水情变化条件下的植被响应机制的研究奠定了基础.

湿地降水一地表水一土壤水-植物水一地下水联系紧密, 水分运移过程复杂, 本文仅对湿地出露条件下芦 苇群落覆盖区的水分运移展开模拟研究, 概化为垂向一维问题. 但鉴于湿地水分运移具有明显区域性, 例如 湿地草甸分布在季节性积水区域,蒸散除土面蒸发和植物蒸腾外,还有水面蒸发,补给来源不仅有降水和深 层土壤水, 还接受地表水补给, 水分补排过程并不相同, 如何克服水文及植物空间分布的不均匀性, 使现行 的水分运移研究由点扩展到面尺度是一个尚待解决的难题.

\section{5 结论}

本文利用 HYDRUS-1D 软件, 模拟分析了鄱阳湖典型湿地芦苇群落区大气一植物、大气一土壤和植物根 系层等界面的水分垂向转化, 主要得出以下结论: (1) 湿地植物根系层土壤水分的主要来源为降水和深层土 壤水, 年补给量达到 1450 和 $609 \mathrm{~mm}$, 主要排泄途径为根系层水分渗漏 $(1053 \mathrm{~mm}$ )、植物蒸腾 (926 mm) 和土 面蒸发 $(176 \mathrm{~mm})$; (2) 湿地土壤水分补排关系受气候、水位波动和植被生长特征等多因素影响,其中降雨人 渗补给和根系层水分渗漏排泄对降雨响应敏感, 主要集中在 4-6月, 分别占年总量的 65\%和 73\%. 土面蒸 发和植物蒸腾主要受气候及植被生长进程的影响,集中在 7-8 月, 分别占年总量的 30\%和 47\%. 深层土壤 向浅层根系层的水分补给集中在气候炎热且地下水浅埋时段 6-8 月,占年总量的 $76 \%$; (3) 受鄱阳湖水位 季节性波动的显著影响, 不同水文时段的根系层水分补排关系不同. 涨水期 (4-6 月) 和枯水期 (12 月至次 年 3 月), 降雨人渗是根系层土壤的主要水分补给来源, 主要排泄为根系层水分渗漏. 丰水期 ( $7-9$ 月), 深 层土壤水是主要补给, 植物蒸腾是主要排泄项. 退水期 ( $10-11$ 月), 降水人渗为主要补给, 土面蒸发与植物 蒸腾为主要排泄项.

本文克服了湿地复杂生境结构导致湿地土壤水、地下水及植物水 (植被蒸腾) 之间水量交换数据连续监 测的困难, 通过数值模拟法量化了不同界面水分通量在日尺度上的连续动态变化, 加强了对湿地水分的来 源构成、排泄去向和界面转化的认识, 弥补了鄱阳湖湿地地下水含水层-土壤-植物-大气连续体水分运移过 程的系统研究方面的不足, 量化了不同水情阶段湿地的补排关系, 为湿地生态系统不同界面水分运移规律 的研究提供重要方法和理论参考.

\section{6 参考文献}

[ 1 ] Zhu Haihong, Zhang Ben, Jiang Jiahu et al eds. Lake Poyang. Hefei: University of Science and Technology of China Press, 1997: 170-172. [ 朱海虹, 张本, 姜加虎等. 中国湖泊系列研究之鄱阳湖. 合肥: 中国科学技术大学出版社, 
1997: 170-172.]

[ 2 ] Deng Wei, Pan Xiangliang, Luan Zhaoqing. Research progress of wetland hydrology. Advances in Water Science, 2003,14 (4) : 521-527. [邓伟, 潘响亮, 亱兆擎. 湿地水文学研究进展. 水科学进展, 2003, 14(4) : 521-527.]

[ 3 ] Yang Jianfeng, Li Baoqing. Preliminary study on the effect of shallow groundwater area diving on SPAC. Journal of Hydraulic Engineering, 1999, (7) : 27-32. [杨建锋, 李宝庆. 浅地下水埋深区潜水对 SPAC 系统作用初步研究. 水利 学报, 1999, (7): 27-32.]

[ 4 ] Gong Zhaoning, Gong Huili, Deng Wei et al. Review on water movement in Groundwater-Soil-Plant-Atmosphere Continuum under shallow groundwater area. Journal of Agro-Environment Science, 2006, 25 (z1) : 365-373. [宫兆宁, 宫 辉力, 邓伟等. 浅埋条件下地下水-土壤-植物-大气连续体中水分运移研究综述. 农业环境科学学报, 2006,25 ( z1 ) : 365-373.]

[ 5 ] Zhang J, van Heyden J, Bendel D et al. Combination of soil-water balance models and water-table fluctuation methods for evaluation and improvement of groundwater recharge calculations. Hydrogeology Journal, 2011, 19(8) : 1487-1502.

[ 6 ] Lei Zhidong, Hu Heping, Yang Shixiu. Progress and review of soil water. Advances in Water Science, 1999, 3 ( 10) : 311 318. [ 雷志栋, 胡和平, 杨诗秀. 土壤水研究进展与评述. 水科学进展, 1999, 3 (10): 311-318.]

[ 7 ] Cheng Zhi, Guo Lianghua, Wang Dongqing et al. Research progress of wetland plant diversity in China. Wetland Science and Management, 2010, (2) : 53-56. [程志, 郭亮华, 王东清等. 我国湿地植物多样性研究进展. 湿地科学与管理, 2010, (2) : 53-56.]

[ 8 ] Cui Baoshan ed. Wetland science. Beijing: Beijing Normal University Press, 2006: 45-55. [崔保山. 湿地学. 北京: 北 京师范大学出版社, 2006: 45-55.]

[ 9 ] Crosslé K, Brock MA. How do water regime and clipping influence wetland plant establishment from seed banks and subsequent reproduction. Aquatic Botany, 2002, 74(1) : 43-56.

[10] Seabloom EW, van der Valk AG, Moloney KA. The role of water depth and soil temperature in determining initial composition of prairie wetland coenoclines. Plant Ecology, 1998, 138(2) : 203-216.

[11] Fraser LH, Karnezis JP. A comparative assessment of seedling survival and biomass accumulation for fourteen wetland plant species grown under minor water-depth differences. Wetlands, 2005, 25(3) : 520-530.

[12] Yu JB, Wang XH, Ning K. Effects of salinity and water depth on germination of Phragmites australis in coastal wetland of the Yellow River delta. Clean-Soil Air Water, 2012, 40(10) : 1154-1158.

[13] Feng Weiwei, Liu Yuanbo. Temporal-spatial characteristics and affecting factors of soil moisture in Lake Poyang watershed from 2003 to 2009. Resources and Environment in the Yangtze, 2015, (2) : 241-250. [冯微微, 刘元波. 2003-2009 年鄱 阳湖流域土壤水分时空变化特征及影响因素. 长江流域资源与环境, 2015, (2): 241-250.]

[14] Chen Jiansheng, Peng Jing, Zhan Lucheng et al. Analysis of the isotope characteristics of river, lake and groundwater in Lake Poyang. Water Resources Protection, 2015，(4): 1-7. [陈建生, 彭靖, 詹沪成等. 鄱阳湖流域河水、湖水及地下 水同位素特征分析. 水资源保护, 2015, (4): 1-7.]

[15] Li Yunliang, Zhang Qi, Li Xianghu et al. Response of hydrological effects to climate change in the Lake Poyang watershed. Resources and Environment in the Yangtze, 2013, 22(10): 1339-1347. [李云良, 张奇, 李相虎等. 鄱阳湖流域水文效 应对气候变化的响应. 长江流域资源与环境, 2013, 22(10): 1339-1347.]

[16] Ye Xuchun, Zhang Qi, Liu Jian et al. Effects of climate change and human activities on runoff variation in Lake Poyang watershed. Glacier Permafrost, 2009, (5) : 835-842. [ 叶许春, 张奇, 刘健等. 气候变化和人类活动对鄱阳湖流域径 流变化的影响研究. 冰川冻土, 2009, (5) : 835-842.]

[17] Tian Peng. Impacts of climate and land use change on runoff, taking the Lake Poyang watershed as an example [Dissertation]. Xi'an: Northwest A \& F University, 2012. [田鹏. 气候与土地利用变化对径流的影响研究一一以鄱阳湖流域 为例 [学位论文]. 西安: 西北农林科技大学, 2012.]

[18] Zhou Wenbin, Wan Jinbao, Jiang Jiahu eds. Influence of water level variation of Lake Poyang on its ecosystem. Beijing: Science Press, 2011. [ 周文斌, 万金保, 姜加虎. 鄱阳湖江湖水位变化对其生态系统影响. 北京: 科学出版 社, 2011.]

[19] Ye Chun, Liu Yuanbo, Zhao Xiaosong et al. Vegetation change of Lake Poyang wetland and its response to water level based on MODIS data. Resources and Environment in the Yangtze, 2013, 22(6): 705-712. [叶春, 刘元波, 赵晓松等. 基于 MODIS 的鄱阳湖湿地植被变化及其对水位的响应研究. 长江流域资源与环境, 2013, 22(6) : 705-712.] 
[20] You Hailin, Xu Ligang, Jiang Jiahu et al. Response of root growth of typical wetland plants in Lake Poyang to extreme water regime change. Chinese Journal of Ecology, 2013, 32(12) : 3125-3130. [游海林, 徐力刚, 姜加虎等. 鄱阳湖典型 洲滩湿地植物根系生长对极端水情变化的响应. 生态学杂志, 2013, 32(12): 3125-3130.]

[21] Zhang Lili, Yin Junxian, Jiang Yunzhong et al. Relationship between wetland vegetation community and hydrological regime in Lake Poyang nature reserve. Advances in Water Science, 2012, 23(6) : 768-775. [张丽丽, 殷峻暹, 蒋云钟等. 鄱阳湖自然保护区湿地植被群落与水文情势关系. 水科学进展, 2012, 23(6): 768-775.]

[22] Hu Zhenpeng, Ge Gang, Liu Chenglin et al. Study on the structure of Lake Poyang wetland plant ecosystem and influence of water level on it. Resources and Environment in the Yangtze, 2010, 19(6): 597-605. [胡振鹏, 葛刚, 刘成林等. 鄱 阳湖湿地植物生态系统结构及湖水位对其影响研究. 长江流域资源与环境, 2010, 19(6) : 597-605.]

[23] Zhao Anna. Response of plant-soil-microbial diversity to hydrological process change in Lake Poyang wetland [ Dissertation]. Nanchang: Nanchang University, 2012. [赵安娜. 鄱阳湖湿地植物-土壤-微生物多样性对水文过程变化的响 应[学位论文]. 南昌: 南昌大学, 2012.]

[24] Šmunek J, Šejna M, Saito H et al. The HYDRUS-1D software package for simulating the movement of water, heat, and multiple solutes in variably saturated media, Version 4.16. U.S.: Department of Environmental Sciences, University of California Riverside, 2013: 9-45.

[25] Ma Huan, Yang Dawen, Lei Huimin et al. Application and improvement of HYDRUS-1D model in field water circulation analysis. Journal of the Society of Agricultural Engineering, 2011, 27(3) : 6-12. [马欢, 杨大文, 雷慧闽等. HYDRUS1D 模型在田间水循环规律分析中的应用及改进. 农业工程学报, 2011, 27(3): 6-12.]

[26] Wang Peng, Song Xianfang, Yuan Ruiqiang et al. Estimation of water flux in farmland SPAC system based on Hydrus-1d model, taking Dong village, Yuncheng Shanxi Province as an example. Geographical Research, 2011, 30(4): 622-634. [王鹏, 宋献方, 袁瑞强等. 基于 Hydrus-1d 模型的农田 SPAC 系统水分通量估算一一山西省运城市董村农场为 例. 地理研究, 2011, 30(4): 622-634.]

[27] Twarakavi NKC, Simunek J, Seo S. Evaluating interactions between groundwater and vadose zone using the HYDRUSbased flow package for MODFLOW. Vadose Zone Journal, 2008, 7(2) : 757-768.

[28] Lai Xiaoming, Liao Kaihua, Zhu Qing et al. Analysis of water leakage and leaching loss of nitrogen and phosphorus in farmland system of Taihu basin based on HYDRUS-1D model. Resources and Environment in the Yangtze, 2015, 24(9) : 1491-1498. [赖晓明, 廖凯华, 朱青等. 基于 HYDRUS-1D 模型的太湖流域农田系统水分渗漏和氮磷淋失特征分 析. 长江流域资源与环境, 2015, 24(9) : 1491-1498.]

[29] Li Shanghua. Simulation of soil water dynamics in degraded wetlands, taking Honghe wetland as an example[Dissertation ]. Beijing: Capital Normal University, 2012. [李尚华. 退化湿地土壤水动态模拟研究一一洪河沼泽湿地为例 [ 学位 论文]. 北京: 首都师范大学, 2012.]

[30] Wang Zhou. Soil moisture dynamic monitoring and simulation of different vegetation communities in Honghe nature reserve of Sanjiang plain[Dissertation]. Beijing: Capital Normal University, 2014. [王舟. 三江平原洪河保护区不同植被群落 土壤水分动态监测与模拟研究 [ 学位论文]. 北京: 首都师范大学, 2014.]

[31] Ma Huan. Analysis of water cycle variation in typical areas of Haihe river basin under the influence of human activities [Dissertation]. Beijing: Tsinghua University, 2011. [马欢. 人类活动影响下海河流域典型区水循环变化分析 [ 学位 论文]. 北京: 清华大学, 2011.]

[32] Richards LA. Capillary conduction of liquids through porous mediums. Physics, 1931, 1(5) : 318-333.

[33] Feddes RA, Bresler E, Neuman SP. Field test of a modified numerical model for water uptake by root systems. Water Resources Research, 1974, 10(6): 1199-1206.

[34] van Genuchten M Th. A numerical model for water and solute movement in and below the root zone. U.S.: Salinity laboratory and USDA, 1987: 206-213.

[35] Allen R, Pereira L, Paes D. Crop evapotranspiration: Guidelines for computing crop water requirements. Rome: Food and Agriculture Organization of the United Nations, 1998 : 56.

[36] Jia Qingyu, Zhou Li, Wang Xiaoying et al. Distribution of radiation in the canopy of phragmites communis in Panjin wetland. Journal of Meteorology and Environment, 2008, 24(4): 19-21. [贾庆宇, 周莉, 王笑影等. 盘锦湿地芦苇群落 冠层内辐射分布特征. 气象与环境学报, 2008, 24(4): 19-21.]

[37] Ritchie JT. Model for predicting evaporation from a row crop with incomplete cover. Water Resources Research, 1972, 8 
(5) : 1204-1213.

[38 ] Xie T, Liu XH, Sun T. The effects of groundwater table and flood irrigation strategies on soil water and salt dynamics and reed water use in the Yellow River Delta, China. Ecological Modeling, 2011, 222(2) : 241-252.

[39] He Chiquan. Physical process of Carex lasiocarpa wetland in Sanjiang plain, transmission of solar radiation in ecosystem. Chinese Journal of Environmental Science, 2001, 21(4) : 376-379. [何池全. 三江平原毛果苔草湿地物理过程一一太 阳辐射能在生态系统中的传输. 中国环境科学, 2001, 21(4) : 376-379.]

[40] Liu Jianli, Xu Shaohui, Liu Hui. Advances in indirect methods for estimating soil water retention curves. Journal of Hydraulic Engineering, 2004, (2) : 68-78. [刘建立, 徐绍辉, 刘慧. 估计土壤水分特征曲线的间接方法研究进展. 水 利学报, 2004, (2): 68-78.]

[41] Schaap MG, Leij FJ, Van Genuchten MTh. Rosetta: A computer program for estimating soil hydraulic parameters with hierarchical pedotransfer functions. Journal of Hydrology, 2001, 251(3/4) : 163-176.

[42] Xie T, Liu XH, Sun T. The effects of groundwater table and flood irrigation strategies on soil water and salt dynamics and reed water use in the Yellow River Delta, China. Ecological Modeling, 2011, 222(2) : 241-252.

[43] Tian Yu, Lei Xiaohui, Jiang Yunzhong et al. Review on sensitivity analysis of hydrological model parameters. Hydrology, 2010, (4) : 9-12. [田雨, 雷晓辉, 蒋云钟等. 水文模型参数敏感性分析方法研究评述. 水文, 2010, (4): 9-12.]

[44] Shao Ming'an, Wang Quanjiu, Huang Mingbin eds. Soil physics. Beijing: Higher Education Press, 2006: 22-23. [邵明 安, 王全九, 黄明斌. 土壤物理学. 北京: 高等教育出版社, 2006: 22-23.]

[45] Liu Yuanbo, Zhang Qi, Liu Jian et al eds. Climatic hydrological processes and water environmental effects in Lake Poyang watershed. Beijing: Science Press, 2012: 135. [刘元波, 张奇, 刘建等. 鄱阳湖流域气候水文过程及水环境效应. 北 京: 科学出版社, 2012: 135.]

[46] Liu Changming, Wang Huixiao et al eds. Process and saving regulation at soil-crop-atmosphere interface. Beijing: Science Press, 1999: 64-67. [刘昌明, 王会肖等. 土壤-作物-大气界面水分过程与节水调控. 北京: 科学出版社, 1999: 64-67. ]

[47] Jennifer E, Pyzoha F, Callahan TJ et al. A conceptual hydrologic model for a forested Carolina bay depressional wetland on the Coastal Plain of South Carolina, USA. Hydrological Processes, 2008, 22(14) : 2689-2697.

[48 ] Jolly ID, Mcewan KL, Holland KL. A review of groundwater-surface water interactions in arid/semi-arid wetlands and the consequences of salinity for wetland ecology. Ecohydrology, 2008, 1(1) : 43-58.

[49] Hou Peng, Jiang Weiguo, Chen Zili et al. Effect of precipitation on hydrology of Lake Dongting wetland. Geographical Research, 2009, 28(2) : 371-377. [侯鹏, 蒋卫国, 陈自力等. 降水对洞庭湖湿地水文补给效应. 地理研究, 2009,28 (2) : 371-377.]

[50 ] Liu Bo, Peng Xiangkai, Shu Longcang et al. Influence of three ecological water replenishment on groundwater in Qingshuigou wetland of the Yellow River. Wetland Science, 2015, 13(4):393-398. [刘波, 彭相楷, 束龙仓等. 黄河三角洲清 水沟湿地三次生态补水对地下水的影响分析. 湿地科学, 2015, 13(4) : 393-398.]

[51] Yan Junhua, Zhou Guoyi, Huang Zhongliang et al. Evapotranspiration of Subtropical Monsoon Evergreen Broad-leaved forests in Dinghu mountain. Forestry Science, 2001, 37(1):37-45. [间俊华, 周国逸, 黄忠良等. 鼎湖山亚热带季风常 绿阔叶林蒸散研究. 林业科学, 2001, 37(1): 37-45.]

[52] Wang Zhi'an, Pei Tiepan. Estimation of evapotranspiration of Broad-leaved Korean Pine forest in Changbai mountains. Chinese Journal of Applied Ecology, 2002, 13(12): 1547-1550. [王志安, 裴铁璠. 长白山阔叶红松林蒸散量的测算. 应 用生态学报, 2002, 13(12): 1547-1550.]

[53] Maayar ME, Chen JM. Spatial scaling of evapotranspiration as affected by heterogeneities in vegetation topography and soil texture. Remote Sensing of Environment, 2006, 102(1/2) : 33-51.

[54] Kuchment LS, Demidow VN. Modeling of influence of hydrological processes on the carbon cycle of a forest ecosystem. Environmental Modeling and Software, 2006, 21(1) : 111-114.

[55] Deng Wei, Luan Zhaoqing, Hu Jinming et al. Study on water flux of typical mire wetland ecosystem in Sanjiang plain. Wetland Science, 2005, 3(1): 32-35. [邓伟, 榇兆擎, 胡金明等. 三江平原典型沼泽湿地生态系统水分通量研究. 湿 地科学, 2005, 3(1): 32-35.]

[56] Xu HF, Jin YM et al. Transpiration rates of Carex meyeriana in relation to micrometerological factors in a mountain valley wetland. Remote Sensing of Environment, 2006, 102(1/2) : 33-51. 
[57] Xie T, Liu XH, Sun T. The effects of groundwater table and flood irrigation strategies on soil water and salt dynamics and reed water use in the Yellow River Delta, China. Ecological Modeling, 2011, 222(2) : 241-252.

[58] Bachand PAM, Bachand S, Fleck J et al. Differentiating transpiration from evaporation in seasonal agricultural wetlands and the link to advective fluxes in the root zone. The Science of the Total Environment, 2013, 484(1): 232-248.

[59] Wang Chaohua. Analysis on variation regularity of farmland evapotranspiration. Hydrology, 2005, 25(3): 35-37. [王朝 华.农田蒸散发量变化规律分析. 水文, 2005, 25(3): 35-37.]

[60] Liang Wenqing. Study on evapotranspiration and crop coefficient of winter wheat and summer maize [Dissertation]. Xi'an: Northwest A \& F University, 2012. [梁文清. 冬小麦、夏玉米蒸发蒸腾及作物系数的研究 [学位论文. 西安: 西北农 林科技大学, 2012.]

[61] Benz LC, Doering EJ, Reichman GA. Alfalfa yields and evapotranspiration response to static water tables and irrigation. Transactions of the ASAE, 1985, 28(4): 1178-1185.

[62] Chen Yaning, Li Weihong, Xu Hailiang et al. Effects of groundwater level on vegetation in the lower reaches of Tarim River. Journal of Geographical Sciences, 2003, 58(4) : 23-27. [陈亚宁, 李卫红, 徐海量等. 塔里木河下游地下水位对 植被的影响. 地理学报, 2003, 58(4): 23-27.]

[63] Sun Yongqiang, Wang Dezhong, Yin Linke et al. Factor analysis of environmental degradation in the lower reaches of Tarim River. Chinese Journal of Soil Science, 2005, 3(3): 22-26. [孙永强, 王德忠, 尹林克等. 塔里木河下游环境退化 的因子分析. 中国水土保持科学, 2005, 3(3): 22-26.] 